\title{
HUBUNGAN TINGKAT PENGETAHUAN DENGAN KEPATUHAN PASIEN HIPERTENSI DI RUMAH SAKIT ANWAR MEDIKA SIDOARJO
}

\author{
Elok Suci Rahayu, Khurin In Wahyuni*, Puspita Raras Anindita
}

Program Studi S1 Farmasi STIKes Rumah Sakit Anwar Medika Sidoarjo

\section{Info Article \\ Submitted : \\ 3 Oktober 2020 \\ Revised :}

7 Januari 2021

Accepted :

9 Januari 2021

\section{Corresponding Author :}

Khurin In Wahyuni

\section{Email :}

khurinain87@gmail.com

\section{ABSTRAK}

Kesadaran dan Pengetahuan tentang hipertensi masih sangat rendah, padahal angka kejadian hipertensi cukup tinggi. Tingkat pengetahuan yang rendah dalam pengobatan merupakan salah satu penyebab kegagalan terapi. Kepatuhan dan ketidakpatuhan dapat digunakan sebagai parameter tingkat pengetahuan pasien hipertensi. Kepatuhan minum obat sangatlah penting karena dengan patuh tekanan darah dapat dikontrol. Rumusan masalah penelitian ini yaitu bagaimana tingkat pengetahuan, tingkat kepatuhan, dan hubungan antara tingkat pengetahuan dengan kepatuhan pasien hipertensi di Rumah Sakit Anwar Medika. Tujuan penelitian ini yaitu untuk mengetahui tingkat pengetahuan, tingkat kepatuhan dan hubungan antara tingkat pengetahuan dengan kepatuhan pasien hipertensi di Rumah Sakit Anwar Medika. Manfaat penelitian ini yaitu Sebagai bahan pertimbangan dan masukkan bagi pasien hipertensi agar mengetahui dampak yang diakibatkan jika tidak patuh dalam menjalankan terapi hipertensi. Penelitian ini merupakan penelitian deskriptif crosssectional. Jumlah sampel pada penelitian ini yaitu 106 pasien dengan menggunakan teknik pengambilan sampel yaitu purposive sampling. Pengumpulan data dilakukan pada bulan Februari sampai Maret 2020 dengan menggunakan kuisioner. Penelitian ini mendapatkan hasil persentase tingkat pengetahuan yaitu pengetahuan rendah $24 \%$, pengetahuan sedang $46 \%$ dan pengetahuan tinggi $30 \%$. Hasil persentase tingkat kepatuhan yaitu kepatuhan rendah $8 \%$, kepatuhan sedang 63\%, dan kepatuhan tinggi $28 \%$. Berdasarkan analisis Chi Square antara pendidikan dengan pengetahuan didapatkan $\mathrm{p}$ value $=0,000(<0,05)$ yang berarti terdapat hubungan antara pendidikan dengan pengetahuan. Berdasarkan analisis Chi Square hubungan antara pendidikan dengan kepatuhan didapatkan $\mathrm{p}$ value $=0,000(<0,05)$ yang berarti terdapat hubungan antara pendidikan dengan kepatuhan. Berdasarkan analisis Korelasi Pearson Product Moment antara tingkat pengetahuan dengan kepatuhan minum obat didapatkan $\mathrm{p}$ value $=0,000(<0,05)$ yang berarti terdapat hubungan signifikan antara tingkat pengetahuan dengan kepatuhan pasien hipertensi di Rumah Sakit Anwar Medika Sidoarjo.

Kata kunci: Hipertensi, Kuisioner, Tingkat Pengetahuan, Tingkat Kepatuhan 
Awareness and knowledge about hypertension is still very low,

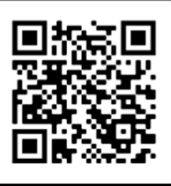

SCAN ME even though the incidence of hypertension is quite high. Low level of knowledge in treatment is one of the causes of therapy failure. Adherence and non-adherence can be used as parameters for the level of knowledge of hypertensive patients. Adherence to taking medication is very important because obediently blood pressure can be controlled. The formulation of the research problem is how the level of knowledge, level of compliance, and the relationship between the level of knowledge and adherence of hypertensive patients at Anwar Medika Hospital. The purpose of this study was to determine the level of knowledge, the level of compliance and the relationship between the level of knowledge and the compliance of hypertensive patients at Anwar Medika Hospital. The benefits of this study are as a consideration and input for hypertensive patients in order to know the impact caused if they do not comply with hypertension therapy. This research is a crosssectional descriptive study. The number of samples in this study were 106 patients using purposive sampling technique. Data collection was carried out from February to March 2020 using a questionnaire. This study found the percentage of knowledge levels, namely low knowledge $24 \%$, moderate knowledge $46 \%$ and high knowledge $30 \%$. The results of the percentage of adherence level are $8 \%$ low adherence, $63 \%$ moderate adherence, and 28\% high compliance. Based on the Chi Square analysis between education and knowledge, it was found that $p$ value $=0.000$ $(<0.05)$, which means that there is a relationship between education and knowledge. Based on the Chi Square analysis, the relationship between education and compliance obtained $p$ value $=0.000(<0.05)$, which means that there is a relationship between education and compliance. Based on the Pearson Product Moment Correlation analysis between the level of knowledge and adherence to taking medication, it was found that $p$ value $=0.000$ $(<0.05)$, which means that there is a significant relationship between the level of knowledge and the compliance of hypertensive patients at Anwar Medika Hospital, Sidoarjo.

Keywords: Hypertension, Questionnaire, Compliance Level, Knowledge Level

\section{PENDAHULUAN}

Hipertensi merupakan keadaan dengan tekanan darah sistolik $>140 \mathrm{mmHg}$ dan tejanan darah diastolik $>90 \mathrm{mmHg}$ (Chobanian, 2004). WHO (World Health Organization) menunjukkan penderita hipertensi di seluruh dunia berjumlah sekitar 1 miliar. Sekitar 8 juta orang yang mengidap hipertensi meninggal dunia setiap tahunnya, dengan kematian terjadi di Asia Tenggara (KemenKes RI, 2016). Berdasarkan hasil dari Riset Kesehatan Dasar (RisKesDas) prevalensi hipertensi di Indonesia pada tahun 2013 sebesar 28,5\%, sedangkan prevalensi hipertensi di Indonesia pada tahun 2017 meningkat menjadi 30,9\% menurut hasil survei Indikator Kesehatan Nasional. Menurut data profil kesehatan Provinsi Jawa Timur prevalensi penyakit hipertensi mencapai 
20,43\%. Prevalensi penyakit hipertensi pada laki-laki sebesar $20,83 \%$ dan perempuan sebesar 20,11\% (KemenKes, 2017).

Faktor risiko hipertensi yaitu umur, jenis kelamin, kebiasaan merokok, konsumsi lemak jenuh, obesitas, kurang aktivitas fisik,dan penggunaan estrogen. Selain faktor tersebut ada beberapa faktor yang mempengaruhi seseorang terkena hipertensi yaitu masih kurangnya pengetahuan dan sikap mengenai hipertensi (Putri, 2018).

$\mathrm{Di}$ Indonesia kesadaran dan pengetahuan tentang penyakit hipertensi masih sangat rendah (Nainggoalan, J. 2014). Pengetahuan pasien hipertensi diperoleh dari media elektronik seperti televisi, radio, internet, membaca majalah atau lewat promosi kesehatan (Widyasari dan Candrasari, 2010).

Kepatuhan dapat digunakan sebagai parameter tingkat pengetahuan pasien melakukan instruksi dari tenaga medis yang berupa pengetahuan tentang resep, meminum obat secara teratur dan tepat, serta merubah gaya hidup. Tujuan pengobatan pada penderita hipertensi adalah untuk meningkatkan kualitas hidup, akan tetapi banyak yang berhenti berobat ketika tubuhnya sedikit membaik, sehingga diperlukan kepatuhan pasien yang menjalani pengobatan hipertensi agar didapatkan kualitas hidup pasien yang lebih baik (Notoatmodjo, 2003).

Hasil penelitian di Poliklinik Penyakit dalam RSUD DR. Moewardi Surakarta membuktikan ada hubungan antara pengetahuan tentang hipertensi dengan pengendalian tekanan darah, responden dengan tingkat pengetahuan baik tentang hipertensi umumnya tekanan darahnya terkendali, sedangkan responden yang mempunyai tingkat pengetahuan tidak baik mengenai hipertensi umumnya tekanan darahnya tidak terkendali (Wulansari dkk, 2013).

Rumah Sakit Anwar Medika merupakan salah satu Rumah Sakit tipe C yang berada di Sidoarjo. Data yang didapat bahwa pasien hipertensi di Rumah Sakit Anwar Medika pada bulan JanuariDesember 2018 sebesar 4.555, dimana pasien hipertensi ini masuk ke dalam 10 besar penyakit tertinggi dengan peringkat kedua pada tahun 2017 sebesar 12.483 pasien dan pada tahun 2018 sebesar 16.002 pasien, sehingga dapat dilihat kasus hipertensi mengalami peningkatan. Dari uraian latar belakang diatas, mendorong untuk melakukan penelitian tentang hubungan tingkat pengetahuan dengan kepatuhan pasien hipertensi di Rumah Sakit Anwar Medika dengan tujuan untuk mengetahui tingkat pengetahuan, kepatuhan, serta hubungan pengetahuan dengan kepatuhan pasien hipertensi di Rumah Sakit Anwar Medika.

\section{METODE PENELITIAN}

Jenis penelitian yang digunakan adalah penelitian yang bersifat observasional analitik dengan pendekatan cross sectional. Jumlah populasi sebanyak 379 sampel. Teknik pengambilan sampel dilakukan dengan teknik purposive sampling. Jumlah sampel responden yaitu 195 responden,dengan kriteria inklusi pasien hipertensi lebih dari 18 tahun, Pasien dengan diagnosis komplikasi dengan atau tanpa komplikasi, Mendapatkan obat atau resep obat antihipertensi dari RS Anwar Medika, Berbahasa indonesia dan dapat berkomunikasi dengan baik, dan Bersedia menjadi responden untuk mengisi kuesioner. Kriteria eksklusi yaitu Pasien hipertensi gestasional (hipertensi pada ibu hamil) dan Pasien memulai pengobatan pada bulan Desember 2019. 
Alat ukur pengetahuan dengan kepatuhan menggunakan kuisioner. Kriteria tingkat pengetahuan dan tingkat kepatuhan dihitung menggunkan standar deviasi dengan bantuan microsoft excel. Uji normalitas menggunakan uji klomogrov smirnov, dan uji hubungan menggunakan uji parametrik pearson product moment.

\section{HASIL DAN PEMBAHASAN}

Penelitian ini dilakukan pada bulan februari sampai maret 2020 di Rumah Sakit Anwar Medika. Pada penelitian ini terdapat kendala yaitu adanya virus Covid-19 sehingga hanya mendapatkan sampel sebanyak 106 responden.

Tabel 1. Karateristik Responden Berdasarkan Usia, Jenis Kelamin, Pekerjaan, dan Pendidikan Terakhir

\begin{tabular}{|c|c|c|c|c|}
\hline No & Karateristik & Kelompok & Frekuensi & Persentase \\
\hline \multirow[t]{3}{*}{1.} & Jenis Kelamin & Laki-laki & 44 & $41,51 \%$ \\
\hline & & Perempuan & 62 & $58,49 \%$ \\
\hline & & Jumlah & 106 & $100 \%$ \\
\hline \multirow[t]{6}{*}{2.} & Umur & $26-35$ & 2 & $1,9 \%$ \\
\hline & & $36-45$ & 10 & $9,43 \%$ \\
\hline & & $46-55$ & 39 & $36,79 \%$ \\
\hline & & $56-65$ & 51 & $48.11 \%$ \\
\hline & & $>65$ & 4 & $3,77 \%$ \\
\hline & & Jumlah & 106 & $100 \%$ \\
\hline \multirow[t]{5}{*}{3.} & Pendidikan & SD & 38 & $35,84 \%$ \\
\hline & & SMP & 28 & $26,41 \%$ \\
\hline & & SMA & 33 & $31,13 \%$ \\
\hline & & S1 & 7 & $6,6 \%$ \\
\hline & & Jumlah & 106 & $100 \%$ \\
\hline \multirow[t]{6}{*}{4.} & Pekerjaan & IRT & 44 & $41,6 \%$ \\
\hline & & Karyawan & 28 & $26,4 \%$ \\
\hline & & PNS & 7 & $6,6 \%$ \\
\hline & & Tidak Bekerja & 14 & $13,2 \%$ \\
\hline & & Lain-lain & 13 & $12,2 \%$ \\
\hline & & Jumlah & 106 & $100 \%$ \\
\hline
\end{tabular}

\section{a) Jenis Kelamin}

Tabel 1 menunjukkan bahwa mayoritas jenis kelamin responden di Rumah Sakit Anwar Medika adalah perempuan yaitu sebanyak 62 responden (58,49\%), hasil penelitian ini sejalan dengan penelitian Wahyuni dan Eksanoto (2013), perempuan (62,8\%) cenderung mengalami hipertensi daripada lakilaki(37,19\%).Perempuan akan mengalami peningkatan resiko tekanan darah tinggi setelah menopause yaitu usia diatas 45 tahun. Perempuan yang belum mengalami menopause dilindungi oleh hormon estrogen yang berperan dalam meningkatkan kadar High Density Lipoprotein (HDL). Kadar kolesterol HDL rendah dan tingginya kolesterol LDL (Low Density Lipoprotein) mempengaruhi terjadinya proses aterosklerosis dan mengakibatkan tekanan darah tinggi. Penelitian lain juga juga berpendapat bahwa pada masa paruh baya lebih tinggi penyakit hipertensi pada wanita ketika seorang wanita mengalami menopause, hal ini terjadi karena wanita yang menopause mengalami penurunan hormon estrogen, yang selama ini 
melindungi pembuluh darah dari kerusakan (Kusumawaty dkk, 2016).

\section{b) Umur}

Tabel 1 menunjukkan bahwa mayoritas umur responden di Rumah Sakit Anwar Medika berumur 56-65 tahun yaitu sebanyak 51 responden $(48,11 \%)$. Penelitian ini sejalan dengan penelitian Tamamilang, dkk (2018) dimana kelompok umur tebanyak mengalami hipertensi yaitu umur 56 sampai 65 (43,8\%). Hal ini karena semakin bertambahnya umur dinding arteri akan mengalami penebalan karena adanya penumpukkan zat kolagen pada lapisan otot sehingga pembuluh darah akan menyempit dan menjadi kaku (Nuraini, 2015).

\section{c) Pendidikan}

Tabel 1 menunjukkan bahwa mayoritas pendidikan responden di Rumah Sakit Anwar Medika adalah berpendidikan SD yaitu sebanyak 38 responden (35,84\%). Penelitian ini sejalan dengan penelitian Santoso dkk (2013) pada 70 penderita hipertensi responden yang paling banyak berpendidikan sekolah dasar yaitu 42 orang (61,4\%). Hasil penelitian ini juga didukung oleh Puspita dkk (2017), menyatakan pendidikan dapat merubah perilaku positif, pendidikan kesehatan juga memberikan suatu informasi kepada seseorang yang akan menyebabkan peningkatan pengetahuannya (Tirtana, 2011).

\section{d) Pekerjaan}

Tabel 1 menunjukkan bahwa mayoritas pekerjaan responden di Rumah Sakit Anwar Medika adalah IRT yaitu sebanyak 38 responden 44 responden $(41,6 \%)$. Penelitian ini sejalan dengan penelitian Isra ddk (2017), pada 68 responden yang paling banyak mengalami hipertensi yaitu memiliki pekerjaan sebagai IRT sebesar 34 orang (50,0\%). Perempuan yang tidak bekerja atau sebagai ibu rumah tangga beresiko lebih tinggi menderita hipertensi dibandingkan dengan perempuan yang bekerja, hal ini karena kurangnya aktifitas fisik yang dapat meningkatkan resiko kelebihan berat badan sehingga beresiko menderita hipertensi (Isra dkk, 2017).

Aktifitas fisik yang kurang cenderung mempunyai frekuensi denyut jantung lebih tinggi sehingga otot jantungnya bekerja lebih keras pada setiap kontraksi (Sheps, 2005).

Tabel 2. Distribusi Responden Berdasarkan Kategori Pengetahuan

\begin{tabular}{lcc}
\hline Pengetahuan & F & \% \\
\hline Rendah & 25 & $24 \%$ \\
Sedang & 49 & $46 \%$ \\
Tinggi & 32 & $30 \%$ \\
Total & $\mathbf{1 0 6}$ & $\mathbf{1 0 0 \%}$ \\
\hline
\end{tabular}

Berdasarkan data hasil pada Tabel 2 dapat dilihat dari 106 responden memiliki pengetahuan rendah sebanyak 25 orang (24\%), Sedang sebanyak 49 (46\%), dan Tinggi sebanyak 32 (30\%). Berdasarkan hasil penelitian ini didapatkan sebagian besar resonden memiliki pengetahuan yang sedang atau cukup. Penelitian ini sejalan dengan penelitian Sefriami (2010), pada 52 responden yang paling banyak memiliki pengetahuan sedang yaitu 38 orang $(73,1 \%)$. Tingkat pengetahuan dapat dipengaruhi beberapa fakror salah satunya adalah pendidikan. Menurut Notoatmojo (2003) pendidikan dapat mempengaruhi tingkat pengetahuan. Pendidikan yang 
direncanakan akan lebih berhasil daripada pendidikan yang tidak direncanakan. Seiring dengan tingginya tingkat pendidikan seseorang maka semakin banyak informasi yang dimiliki (Sefriami,2010).

Tabel 3. Distribusi Responden Berdasarkan Kategori Kepatuhan

\begin{tabular}{lcc}
\hline Kepatuhan & F & $\%$ \\
\hline Rendah & 9 & $8,50 \%$ \\
Sedang & 67 & $63,2 \%$ \\
Tinggi & 30 & $28,3 \%$ \\
Total & $\mathbf{1 0 6}$ & $\mathbf{1 0 0 \%}$ \\
\hline
\end{tabular}

Berdasarkan hasil pada tabel 3 dapat dilihat dari 106 responden memiliki kepatuhan rendah sebanyak 9 orang $(8,50 \%)$, sedang sebanyak 67 orang $(63,2 \%)$, dan tinggi sebanyak 30 orang $(28,3 \%)$. Berdasarkan hasil penelitian ini didapatkan sebagian besar reponden memiliki kepatuhan yang sedang atau cukup.

Penelitian ini sejalan dengan penelitian Anwar dan Masnina (2019), dari
83 responden yang memiliki kepatuhan sedang sebanyak 34 responden (41,0\%). Responden memiliki kepatuhan sedang menunjukkan adanya kesadaran bahwa gejala dan komplikasi hipertensi dapat muncul mengganggu aktifitas sehingga berkeinginan untuk mengontrol tekanan darah dengan patuh minum obat. Kepatuhan sedang juga merupakan tahap dari perubahan perilaku dimana tahap ini masih perlu pengawasan (Ningrum, 2018).

Tabel 4. Uji Normalitas

\begin{tabular}{cc} 
Uji Normalitas & $\begin{array}{c}\text { Asymp. Sig. } \\
\text { (2-sided) }\end{array}$ \\
\hline Klomogrov smirnov & 0,497 \\
\hline
\end{tabular}

Tabel 5. Distribusi Hubungan Karateristik Responden dengan Pengetahuan Menggunakan Uji Chi Squere

\begin{tabular}{|c|c|c|c|c|c|}
\hline \multirow[t]{2}{*}{ Kelompok } & \multicolumn{3}{|c|}{ Pengetahuan } & \multirow[t]{2}{*}{ Total } & \multirow{2}{*}{$\begin{array}{l}\text { Asymp. } \\
\text { Sig. } \\
\text { (2-sided) }\end{array}$} \\
\hline & Rendah & Sedang & Tinggi & & \\
\hline \multicolumn{6}{|l|}{ Jenis Kelamin } \\
\hline Laki-Laki & $\begin{array}{c}7 \\
(15,9 \%) \\
\end{array}$ & $\begin{array}{c}21 \\
(47,7 \%) \\
\end{array}$ & $\begin{array}{c}16 \\
(36,4 \%)\end{array}$ & $\begin{array}{c}44 \\
(100 \%) \\
\end{array}$ & \multirow{2}{*}{$\begin{array}{c}\text { 0,239 } \\
\text { (Tidak } \\
\text { Bermakna) }\end{array}$} \\
\hline Perempuan & $\begin{array}{c}18 \\
(29,0 \%) \\
\end{array}$ & $\begin{array}{c}28 \\
(45,2 \%)\end{array}$ & $\begin{array}{c}16 \\
(25,8 \%)\end{array}$ & $\begin{array}{c}62 \\
(100 \%)\end{array}$ & \\
\hline \multicolumn{6}{|l|}{ Umur } \\
\hline $26-35$ & $\begin{array}{c}0 \\
(0.0 \%) \\
\end{array}$ & $\begin{array}{c}1 \\
(50,0 \%) \\
\end{array}$ & $\begin{array}{c}1 \\
(50,0 \%)\end{array}$ & $\begin{array}{c}2 \\
(100 \%)\end{array}$ & \multirow{5}{*}{$\begin{array}{c}\text { 0,525 } \\
\text { (Tidak } \\
\text { Bermakna) }\end{array}$} \\
\hline $36-45$ & $\begin{array}{c}1 \\
(9,1 \%)\end{array}$ & $\begin{array}{c}4 \\
(36,4 \%)\end{array}$ & $\begin{array}{c}6 \\
(54,5 \%)\end{array}$ & $\begin{array}{c}11 \\
(100 \%)\end{array}$ & \\
\hline $46-55$ & $\begin{array}{c}9 \\
(23,7 \%) \\
\end{array}$ & $\begin{array}{c}18 \\
(47,7 \%) \\
\end{array}$ & $\begin{array}{c}11 \\
(28,9 \%) \\
\end{array}$ & $\begin{array}{c}38 \\
(100 \%) \\
\end{array}$ & \\
\hline $56-65$ & $\begin{array}{c}15 \\
(29,4 \%) \\
\end{array}$ & $\begin{array}{c}24 \\
(47,1 \%)\end{array}$ & $\begin{array}{c}12 \\
(23,5 \%)\end{array}$ & $\begin{array}{c}51 \\
(100 \%) \\
\end{array}$ & \\
\hline$>65$ & $\begin{array}{c}0 \\
(0,0 \%)\end{array}$ & $\begin{array}{c}2 \\
(50,0 \%)\end{array}$ & $\begin{array}{c}2 \\
(50,0 \%)\end{array}$ & $\begin{array}{c}4 \\
(100 \%) \\
\end{array}$ & \\
\hline
\end{tabular}




\begin{tabular}{|c|c|c|c|c|c|}
\hline Pendidikan & & & & & \multirow{5}{*}{$\begin{array}{c}0,000 \\
\text { (Bermakna) }\end{array}$} \\
\hline SD & $\begin{array}{c}19 \\
(50,0 \%)\end{array}$ & $\begin{array}{c}14 \\
(36,8 \%)\end{array}$ & $\begin{array}{c}5 \\
(13,2 \%)\end{array}$ & $\begin{array}{c}38 \\
(100 \%)\end{array}$ & \\
\hline SMP & $\begin{array}{c}2 \\
(7,1 \%)\end{array}$ & $\begin{array}{c}22 \\
(78,6 \%)\end{array}$ & $\begin{array}{c}4 \\
(14,3 \%)\end{array}$ & $\begin{array}{c}28 \\
(100 \%)\end{array}$ & \\
\hline SMA & $\begin{array}{c}2 \\
(6,1 \%) \\
\end{array}$ & $\begin{array}{c}12 \\
(36,4 \%) \\
\end{array}$ & $\begin{array}{c}19 \\
(57,6 \%)\end{array}$ & $\begin{array}{c}33 \\
(100 \%)\end{array}$ & \\
\hline S1 & $\begin{array}{c}2 \\
(28,6 \%)\end{array}$ & $\begin{array}{c}1 \\
(14,3 \%)\end{array}$ & $\begin{array}{c}4 \\
(57,1 \%)\end{array}$ & $\begin{array}{c}7 \\
(100 \%)\end{array}$ & \\
\hline \multicolumn{6}{|l|}{ Pekerjaan } \\
\hline IRT & $\begin{array}{c}13 \\
(29,5 \%)\end{array}$ & $\begin{array}{c}20 \\
(45,5 \%)\end{array}$ & $\begin{array}{c}11 \\
(25,0 \%)\end{array}$ & $\begin{array}{c}44 \\
(100 \%)\end{array}$ & \multirow{5}{*}{$\begin{array}{c}\text { 0,376 } \\
\text { (Tidak } \\
\text { Bermakna) }\end{array}$} \\
\hline Karyawan & $\begin{array}{c}3 \\
(10,7 \%)\end{array}$ & $\begin{array}{c}12 \\
(42,9 \%)\end{array}$ & $\begin{array}{c}13 \\
(46,4 \%)\end{array}$ & $\begin{array}{c}28 \\
(100 \%)\end{array}$ & \\
\hline Lain-lain & $\begin{array}{c}3 \\
(23,1 \%)\end{array}$ & $\begin{array}{c}8 \\
(61,5 \%)\end{array}$ & $\begin{array}{c}2 \\
(15,4 \%)\end{array}$ & $\begin{array}{c}13 \\
(100 \%)\end{array}$ & \\
\hline PNS & $\begin{array}{c}2 \\
(28,6 \%) \\
\end{array}$ & $\begin{array}{c}2 \\
(28,6 \%) \\
\end{array}$ & $\begin{array}{c}3 \\
(42,9 \%) \\
\end{array}$ & $\begin{array}{c}7 \\
(100 \%) \\
\end{array}$ & \\
\hline Tidak Bekerja & $\begin{array}{c}4 \\
(28,6 \%)\end{array}$ & $\begin{array}{c}7 \\
(50,0 \%)\end{array}$ & $\begin{array}{c}3 \\
(21,4 \%)\end{array}$ & $\begin{array}{c}14 \\
(100 \%)\end{array}$ & \\
\hline
\end{tabular}

Berdasarkan data hasil uji statistik pada tabel 5menunjukkan bahwa tidak terdapat hubungan antara tingkat pengetahuan dengan jenis kelamin, umur, dan pekerjaan hal ini dapat dilihat bahwa nilai Sig yang didapat $>0,05$ yang menunjukkan bahwa tidak terdapat hubungan.

Berdasarkan data hasil analisis uji Chi-Square Tests pata tabel 5 dapat diketahui nilai Sig $0,000 \quad(<0,05)$ yang artinya terdapat hubungan antara pendidikan dengan pengetahuan pasien hipertensi, semakin tinggi pendidikan maka semakin tinggi pula tingkat pengetahuannya. Penelitian ini sejalan dengan penelitian Shiombing dkk (2017) yaitu pada penelitian tersebut responden yang memiliki tingkat pengetahuan baik adalah responden dengan tingkat pendidikan tinggi (40\%). Semakin tinggi tingkat pendidikan seseorang maka pengetahuannya semakin baik, sehingga hal tersebut berakibat pada peningkatan potensi diri untuk menjaga, mempertahankan dan meningkatkan kesehatan, namun tingkat pendidikan rendah dapat mengakses informasi dari media umum yang tersedia (Shiombing dkk, 2017).

Tabel 6. Distribusi Hubungan Karateristik Responden dengan Kepatuhan Menggunakan Uji Chi Squere

\begin{tabular}{|c|c|c|c|c|c|}
\hline \multirow[t]{2}{*}{ Kelompok } & \multicolumn{3}{|c|}{ Kepatuhan } & \multirow[t]{2}{*}{ Total } & \multirow{2}{*}{$\begin{array}{l}\text { Asymp. } \\
\text { Sig. } \\
\text { (2-sided) }\end{array}$} \\
\hline & Rendah & Sedang & Tinggi & & \\
\hline \multicolumn{6}{|l|}{ Jenis Kelamin } \\
\hline Laki-Laki & $\begin{array}{c}4 \\
(9,1 \%)\end{array}$ & $\begin{array}{c}25 \\
(56,8 \%) \\
\end{array}$ & $\begin{array}{c}15 \\
(34,1 \%) \\
\end{array}$ & $\begin{array}{c}44 \\
(100 \%) \\
\end{array}$ & \multirow{2}{*}{$\begin{array}{c}\text { 0,494 } \\
\text { (Tidak } \\
\text { Bermakna) }\end{array}$} \\
\hline Perempuan & $\begin{array}{c}5 \\
(8,1 \%) \\
\end{array}$ & $\begin{array}{c}42 \\
(67,7 \%)\end{array}$ & $\begin{array}{c}15 \\
(24,2 \%)\end{array}$ & $\begin{array}{c}62 \\
(100 \%)\end{array}$ & \\
\hline \multicolumn{5}{|l|}{ Umur } & \multirow{3}{*}{$\begin{array}{c}0,805 \\
\text { (Tidak } \\
\text { Bermakna) }\end{array}$} \\
\hline $26-35$ & $\begin{array}{c}0 \\
(0.0 \%)\end{array}$ & $\begin{array}{c}1 \\
(50,0 \%)\end{array}$ & $\begin{array}{c}1 \\
(50,0 \%)\end{array}$ & $\begin{array}{c}2 \\
(100 \%)\end{array}$ & \\
\hline $36-45$ & 1 & 5 & 5 & 11 & \\
\hline
\end{tabular}




\begin{tabular}{|c|c|c|c|c|c|}
\hline & & & & & \\
\hline & $(9,1 \%)$ & $(45,5 \%)$ & $(45,5 \%)$ & $(100 \%)$ & \\
\hline $46-55$ & $\begin{array}{c}3 \\
(7,9 \%)\end{array}$ & $\begin{array}{c}24 \\
(63,2 \%)\end{array}$ & $\begin{array}{c}11 \\
(28,9 \%)\end{array}$ & $\begin{array}{c}38 \\
(100 \%)\end{array}$ & \\
\hline $56-65$ & $\begin{array}{c}5 \\
(9,8 \%)\end{array}$ & $\begin{array}{c}35 \\
(68,6 \%)\end{array}$ & $\begin{array}{c}11 \\
(21,6 \%)\end{array}$ & $\begin{array}{c}51 \\
(100 \%)\end{array}$ & \\
\hline$>65$ & $\begin{array}{c}0 \\
(0,0 \%)\end{array}$ & $\begin{array}{c}2 \\
(50,0 \%) \\
\end{array}$ & $\begin{array}{c}2 \\
(50,0 \%) \\
\end{array}$ & $\begin{array}{c}4 \\
(100 \%) \\
\end{array}$ & \\
\hline Pendidikan & & & & & \multirow{5}{*}{$\begin{array}{c}0,000 \\
\text { (Bermakna) }\end{array}$} \\
\hline SD & $\begin{array}{c}8 \\
(21,1 \%)\end{array}$ & $\begin{array}{c}23 \\
(60,5 \%)\end{array}$ & $\begin{array}{c}7 \\
(18,4 \%)\end{array}$ & $\begin{array}{c}38 \\
(100 \%)\end{array}$ & \\
\hline SMP & $\begin{array}{c}0 \\
(0,0 \%) \\
\end{array}$ & $\begin{array}{c}24 \\
(85,7 \%) \\
\end{array}$ & $\begin{array}{c}4 \\
(14,3 \%) \\
\end{array}$ & $\begin{array}{c}28 \\
(100 \%) \\
\end{array}$ & \\
\hline SMA & $\begin{array}{c}0 \\
(0,0 \%)\end{array}$ & $\begin{array}{c}18 \\
(54,4 \%)\end{array}$ & $\begin{array}{c}15 \\
(45,5 \%) \\
\end{array}$ & $\begin{array}{c}33 \\
(100 \%) \\
\end{array}$ & \\
\hline S1 & $\begin{array}{c}1 \\
(14,3 \%) \\
\end{array}$ & $\begin{array}{c}2 \\
(28,6 \%)\end{array}$ & $\begin{array}{c}4 \\
(57,1 \%)\end{array}$ & $\begin{array}{c}7 \\
(100 \%)\end{array}$ & \\
\hline \multicolumn{6}{|l|}{ Pekerjaan } \\
\hline IRT & $\begin{array}{c}4 \\
(9,1 \%)\end{array}$ & $\begin{array}{c}31 \\
(70,5 \%)\end{array}$ & $\begin{array}{c}9 \\
(20,5 \%)\end{array}$ & $\begin{array}{c}44 \\
(100 \%)\end{array}$ & \multirow{5}{*}{$\begin{array}{c}0,185 \\
\text { (Tidak } \\
\text { Bermakna) }\end{array}$} \\
\hline Karyawan & $\begin{array}{c}2 \\
(7,1 \%) \\
\end{array}$ & $\begin{array}{c}13 \\
(46,4 \%) \\
\end{array}$ & $\begin{array}{c}13 \\
(46,4 \%) \\
\end{array}$ & $\begin{array}{c}28 \\
(100 \%)\end{array}$ & \\
\hline Lain-lain & $\begin{array}{c}2 \\
(15,4 \%) \\
\end{array}$ & $\begin{array}{c}8 \\
(61,5 \%)\end{array}$ & $\begin{array}{c}3 \\
(23,1 \%)\end{array}$ & $\begin{array}{c}13 \\
(100 \%)\end{array}$ & \\
\hline PNS & $\begin{array}{c}1 \\
(14,3 \%)\end{array}$ & $\begin{array}{c}3 \\
(42,9 \%)\end{array}$ & $\begin{array}{c}3 \\
(42,9 \%)\end{array}$ & $\begin{array}{c}7 \\
(100 \%)\end{array}$ & \\
\hline Tidak Bekerja & $\begin{array}{c}0 \\
(0,0 \%)\end{array}$ & $\begin{array}{c}12 \\
(85,7 \%)\end{array}$ & $\begin{array}{c}2 \\
(14,3 \%)\end{array}$ & $\begin{array}{c}14 \\
(100 \%)\end{array}$ & \\
\hline
\end{tabular}

Berdasarkan data hasil uji statistik pada tabel 6 menunjukkan bahwa tidak terdapat hubungan antara tingkat kepatuhan dengan jenis kelamin, umur, dan pekerjaan hal ini dapat dilihat bahwa nilai Sig yang didapat $>0,05$ yang menunjukkan bahwa tidak terdapat hubungan.

Berdasarkan data hasil pada tabel 6 Pada analisis uji Chi-Square Tests dapat diketahui nilai Sig $0,000 \quad(<0,05)$ yang artinya terdapat hubungan antara pendidikan dengan kepatuhan pasien hipertensi. Penelitian ini sejalan dengan penelitian Sinuraya dkk (2018) dimana pada penelitian ini tingkat pendidikan memiliki korelasi signifikan terhadap kepatuhan responden $(p=0,009)$. Responden yang berpendidikan tinggi lebih patuh menjalani pengobatan dibandingkan responden yang berpendidikan rendah, hal ini karena responden yang berpendidikan tinggi memiliki pengetahuan yang tinggi tentang bagaimana menjaga kesehatannya (Fitrina dan Harysko, 2014).

Tabel 7. Uji Korelasi Pearson Product Moment

\begin{tabular}{ccc}
\hline Uji Korelasi & $\begin{array}{c}\text { Asymp. Sig. } \\
\text { (2-sided) }\end{array}$ & Pearson Correlation \\
\hline Uji Pearson Product Moment & 0,000 & 0,619 \\
\hline
\end{tabular}

Berdasarkan hasil penelitian yang dilakukan diketahui bahwa responden memiliki pengetahuan dan kepatuhan yang sedang atau cukup. Berdasarkan data hasil pada tabel 7 uji Korelasi Pearson Product Moment dari 106 responden, 
diperoleh nilai Sig 0,000 $(<0,05)$, Hal dapat diartikan terdapat hubungan signifikan antara tingkat pengetahuan dengan kepatuhan pasien hipertensi di Rumah Sakit Anwar Medika. Keeratan hubungan dua variabel ini yaitu berkorelasi kuat hal ini sesuai dengan literature jika nilai Pearson correlation 0,61-0,80, maka korelasi kuat (Hasan, 2006).

Penelitian ini sejalan dengan penelitian Pratiwi dan perwitasari (2017), dimana pada penelitian tersebut didapat uji statistik dengan nilai Sig 0,000 $(<0,05)$. Tingkat pengetahuan merupakan salah satu faktor yang dapat mempengaruhi kepatuhan seseorang dalam pengobatannya. Tingginya tingkat pengetahuan akan menunjukkan seseorang telah mengetahui, mengerti, dan memahami maksud dari pengobatan yang telah dijalani (Pratama, 2015). Penderita hipertensi yang memiliki pengetahuan yang tinggi lebih patuh daripada pasien yang memiliki pengetahuan rendah (Mathavan\&Ngurah, 2017).

Hasil penelitian Rasajati dkk (2015) juga mendapatkan hasil uji statistik dengan niali Sig 0,000 $(<0,05)$ yang menunjukkan terdapat hubungan antara pengetahuan dengan kepatuhan pengobatan. Responden yang memiliki pengetahuan hipertensi tinggi cenderung lebih patuh melakukan pengobatan dibandingkan dengan responden yang memiliki pengetahuan rendah, hal ini karena responden yang memiliki pengetahuan tinggi lebih memahami bagaimana pengobatan hipertensi yang benar dan bahayanya apabila tidak rutin minum obat sehingga responden lebih patuh dalam melakukan pengobatan.

Penelitian ini tidak sejalan dengan penelitian Mbakurawang dan Agustine (2015) yang menyatakan bahwa tidak terdapat hubungan yang signifikan antara pengetahuan dan tingkat kepatuhan pasien hipertensi dengan hasil analisis $p=0,476(>0,05)$, penelitian tidak sejalan disebabkan tingkat kepatuhan seseorang dalam pengobatan bukan hanya dipengaruhi oleh pengetahuan saja tetapi bisa dipengaruhi oleh faktor lain seperti sikap, keyakinan, kehendak, dan motivasi (Mbakurawang dan Agustine, 2015).

\section{KESIMPULAN}

Berdasarkan penelitian yang telah dilakukan dapat disimpulkan Pengetahuan pasien hipertensi di Rumah Sakit Anwar Medika termasuk kategori rendah 24\%, sedang 46\%, dan tinggi 30\%. Kepatuhan pasien hipertensi di Rumah Sakit Anwar Medika termasuk kategori rendah 8,50\%, sedang $63,2 \%$, dan tinggi $28,3 \%$. Terdapat hubungan antara tingkat pengetahuan dengan kepatuhan pasien hipertensi di Rumah Sakit Anwar Medika dengan hasil Sig 0,000 $(<0,05)$ dan keeratan hubungan yang kuat.

\section{UCAPAN TERIMA KASIH}

Peneliti mengucapkan terimakasih kepada semua pihak yang terkait dengan penelitian ini. Ucapan terimakasih juga saya sampaikan kepada pihak Rumah Sakit Anwar Medika Sidoarjo yang memberikan fasilitas untuk menunjang penelitian ini.

\section{DAFTAR PUSTAKA}

Anwar, K., Masnina, R. 2019. Hubungan Kepatuhan Minum Obat Antihipertensi denganTekanan Darah Pada Lansia Penderita Hipertensi di Wilayah Kerja Puskesmas Air Putih Samarinda. Borneo Student Research.

Chobainon, A. V. 2004. The Seventh Report of the Joint National Committee on : Prevention, Detection, Evaluation, and Treatment of High Blood Pressure. $7^{\text {th }}$ Ed.United State of Amerikan American. NIH Publication. 
Fitrina, Y., Harysko, R.O. 2014. Hubungan Karateristik Dan Motivasi Pasien Hipertensi Terhadap Kepatuhan dalam Menjalkani Pengobatan Di Puskesmas Talang Kabupaten Solok Tahun 2014.

Isra, M., Bisnu, K. H., Kepel, B. L. Mulyadi. 2017. Hubungan Dukungan Keluarga Dengan Derajat Hipertensi Pada Pasien Hipertensi Di Puskesmas Ranomut Kota Manado. eJournal Keperawatan (e-KP).5 (1).

KemenKes RI. 2016. Profil Data Kesehatan Indonesia Tahun 2015. Jakarta:Kementerian Kesehatan RI.

Kementerian Kesehatan Republik Indonesia. 2017. Hipertensi. Jakarta: Pusat Data dan Informasi Kementerian Kesehatan Republik Indonesia.

Kusumawaty, J., Hidayat, N., Ginanjar, E. 2016. Hubungan Jenis Kelamin dengan Intensitas Hipertensi pada Lansia di Wilayah Kerja Puskesmas Lakbok Kabupaten Ciamis. Mutiara Medika.16(2): 46-51.

Mathavan, J., Ngurah, G. 2017. Gambaran tingkat pengetahuan terhadap hipertensi dan kepatuhan minum obat pada penderita hipertensi di wilayah kerja Puskesmaskintamani I, Bangli-Bali. Bali: IntisariSainsMedis.

Mbakurawang, I. N., Agustine, U. Kepatuhan Minum Obat Pada Penderita Hipertensi Yang Berobat Ke Balai Pengobatan Yayasan Pelayanan Kasih A dan A Rahmat Waingapu. Jurnal poltekes kupang.

$\begin{array}{lll}\text { Ningrum, } & \text { S. } & \text { P. }\end{array}$ HubungaDukunganKeluargaDenganKep atuhanMinumObatPasienHipertensi Di PuskesmasSeyeganSleman Yogyakarta. NaskahPublikasi. Sekolah Tinggi IlmuKesehatan'aisyiyah Yogyakarta.

Notoatmojo, S. 2003 PendidikandanPerilakuKesehatan. Jakarta: RinekaCipta.

Notoatmodjo, 2007. PromosiKesehatandanllmuPerilaku. Jakarta: RhinekaCipta.

Nuraini B. 2015. Risk Factors Of Hypertension.J MAJORITY . 4(5).

Nursalam. 2001. DokumentasiKeperawatan. Jakarta: ECG.

Pratiwi, R. I., danPerwitasari, M. 2017 AnalisisFaktor-Faktor Yang
MempengaruhiKepatuhanPasienHiperte nsiDalamPenggunaanObat $\mathrm{Di}$ RSUD Kardinah. Seminar Nasional IPTEK Terapan (SENIT) 2017. PoliteknikHarapanBersama, Tegal.

Puspita, E., Oktaviarini, E., Santik, Y. D. P. 2017. PeranKeluarga Dan PetugasDalamKepatuhanPengobatanPe nderitaHipertensi PuskesmasGubungpati Kota Semarang. JurnalKesehatanMasyarakat. 12(2).

Putri, H. 2018. Upaya Peningkatan Pengetahuan Tentang Hipertensi Melalui Metode Ppenyuluhan. Yogyakarta: Jurnal Pemberdayaan: Publikasi Hasil Pengabdian Kepada Masyarakat. 2(1), 171-176.

Rasajati, Q.P., Raharjo, B.B., Ningrum, D.N.A. 2015. Faktor-Faktor yang Berhubungan dengan Kepatuhan Pengobatan Pada Penderita Hipertensi Di Wilayah Kerja Puskesmas Kedungmundu Kota Semarang. Unnes Journal of Public Health. 4 (3).

Sefriami., Asnindari, L.N. 2010. Hubungan Tingkat Pengetahuan Dengan Pengelolaan Hipertensi Pada Penderita Hipertensi Di RT 10-12 Kelurahan Pandeyan Umbulharjo Kota Yogyakarta. Naskah Publikasi. Sekolah Tinggi IImu Kesehatan'aisyiyah Yogyakarta.

Sheps, S. G., 2005. Mayo Clinic Hipertensi, Mengatasi Tekanan Darah Tinggi. Jakarta. PT Intisari Mediatama.

Shiombing, T. F. H., Artini, A. A. 2017.Tingkat Pengetahuan Mengenai Hipertensi dan Pola Kepatuhan Pengobatan pada Penderita Hipertensi yang Berkunjung ke Tenda Tensi Tim Bantuan Medis Janar Dūta Fakultas Kedokteran Universitas Udayana. E-Jurnal Medika. 6 (12).

Sinuraya, R.K., Destiani, D. P., Puspitasari, I.M., Diantini, A. 2018. Tingkat Kepatuhan Pengobatan Pasien Hipertensi di Fasilitas Kesehatan Tingkat Pertama di Kota Bandung. Jurnal Farmasi Klinik Indonesia. 7 (2): 124-133.

Sulistyarini, T., dan Hapsari, M. F. 2015 Delapan Faktor Penting Yang Mempengaruhi Motivasi Kepatuhan Minum Obat Pasien Hipertensi. Jurnal STIKES. 8(1).

Tamamilang, C. D., Kandou G. D., Nelwan J. E. 2018. Hubungan Antara Umur Dan 
Aktivitas Fisik Dengan Derajat Hipertensi Di Kota Bitung Sulawesi Utara. Jurnal KESMAS. 7 (5).

Tirtana, A. 2011. Pengaruh Pendidikan Kesehatan Terhadap Pengetahuan Hipertensi Pada Lansia Hipertensi Di RW 04 Tegal Rejo Kelurahan Tegal Rejo Tahun 2011. Naskah Publikasi. Sekolah Tinggi Ilmu Keperawatan 'Aisyiyah Yogyakarta.

Wahyuni., dan Eksanoto, D. 2013. Hubungan Tingkat Pendidikan dan Jenis Kelamin dengan Kejadian Hipertensi di Kelurahan Jagalan di Wilayah Kerja Puskesmas
Pucang Sawit Surakarta. Jurnal IImu KeperawatanIndonesia. 1 (1).

Widyasari, D. F., Candrasari, M. 2010. Pengaruh Pendidikan Tentang Hipertensi terhadap Perubahan dan Sikap Lansia di Desa Makamhaji Kartasura Sukoharjo. Biomedika. 2(2).

Wulansari, J. Ichsan, B. dan Usdiana, D. 2013. Hubungan Pengetahuan Tentang Hipertesi Dengan Pengendaalian Tekanan Darah Pada Pasien Hipertensi Di Poliklinik Penyakit Dalam RSUD DR. Moewardi Surakarta. Biomedika. 5 (1). 